\section{Homo exquisitus}

\section{R. D. Meikle}

Ehret: Flower Painter Extraordinary. By Gerta Calmann. Pp. 160. (Phaidon: Oxford, 1977.) £16.

THE history of Georg Dionysius Ehret (1708-1770) exemplifies the plight of many a botanical artist, dismissed (until recently) as a technician by the world of Art, and used, but scarcely appreciated, by botanists, to whom such elegant work seems to be of little more than peripheral importance.

Ehret was born in Heidelberg (or possibly Erfurt), the son of a gardener, with no advantages of birth save an observant eye and a natural talent for drawing and painting flowers. After a brief apprenticeship in horticulture, he turned to botanical illustration, serving a succession of patrons, who, it would seem, were rather more anxious to exploit his genius than to reward it. In many ways, his life resembles that of Mozart: plenty of appreciation, and no lack of hospitality, but probably always an acute shortage of cash. Like Mozart, his strivings for a measure of independence were labelled giddiness by his betters: "he is homo exquisitus in everything, he has only one fault, he is flighty".

His end was not a tragic one, perhaps because he had the good sense to head for England, where in time he became something of a celebrity, commending himself to Mrs Delany and the Duchess of Portland, and no doubt discovering that nothing is more acceptable to the English than an imperfect command of their language; for, even after thirty years' residence, he could barely make himself understood. In view of his reputed flightiness, even the daunting task of teaching the daughters of the nobility how to draw and paint flowers may have had its rewarding moments.

From his arrival in England, in 1736, until his death thirty-four years later, Ehret's life seems to have been tolerably pleasant, and was certainly very productive. It was not, however, the sort of life that was likely to contribute to his lasting fame. Much of his best work remained unpublished. Splendid paintings on paper and vellum may have given momentary gratification to the proud owners of stoves and exotica, but they were soon filed away and forgotten. The published engravings, even those in Linnaeus's Hortus
Cliffortianus and his own Plantae et Papiliones Rariores can scarcely be judged more than competent, whereas those in Trew's Plantae Selectae and Hortus Nitidissimus are sometimes mere travesties of the originals, almost as lifeless as the text which they accompany. Furthermore, the very works which Ehret illustrated ceased to be of more than scholarly and historic interest once the simple binomial system of plant nomenclature had been fully grasped.

Ehret was the contemporary (and avowedly the friend) of Linnaeus, but, in company with many of his patrons, he failed to appreciate the Linnean revolution in plant-naming, and continued to cling to "pre-Linnean" phrase-names long after the publication of the Species Plantarum (1753). It is for this reason that the writings of Miller, Aiton and even the ingenious Hill are still valued, whereas those of Trew and Weinmann were outmoded almost as soon as they left the press. $\mathrm{Had}$ it not been for the recent revival of interest in Ehret as an artist, there can be little doubt that his eclipse would have been total. In the unsympathetic world of taxonomy, he is, even now, little more than a penumbra.

Dr Gerta Calmann's monograph should dispel some of the shadows. But Ehret is a difficult person to write about. He was forever on the move, flitting, like one of his butterflies, from flower to flower and from patron to patron, without leaving any record of his activities save numerous signed and dated pictures and a brief autobiographical sketch specially designed to ease his entry into the Imperial German Academy of Naturalists. To make sense of such a complex and disjointed career, it is necessary to plan carefully and prune rigorously. Unfortunately,

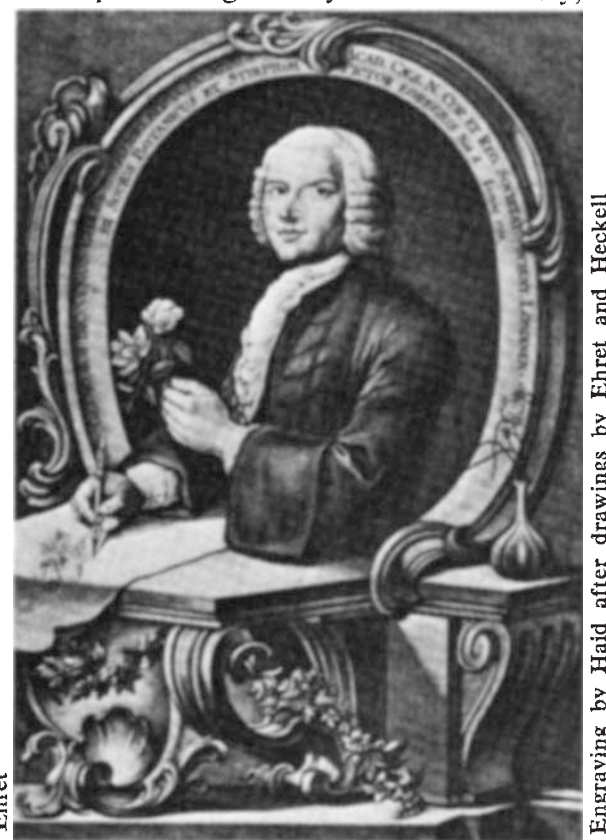

Dr Calmann seems to have caught some of the flightiness from her subject. The text is widely informative, and often entertaining, but however much one may be amused by the antics of the Marcgrave of Baden-Durlach and his troop of female hussars, these, and similar digressions, do not help to concentrate one's mind on the essentials. Moreover, the author's frank admission that she is not a botanist does not excuse the astonishing string of errors on p48. Here, we are told that, "In a flash of insight Linnaeus realised that stamens and pistils were the sexual organs of plants", that his "artificial" system "was superseded finally by Darwin's theory of evolution", and that Linnaeus "created botanical Latin which simplified the identification of plants". Such obiter dicta do not necessarily impair the validity of the remaining text; but they undermine one's confidence.

The coloured illustrations, despite some, possibly unavoidable, reduction, are generally good, certainly very much better than many of the reproductions which appeared in Ehret's own lifetime. They have been selected to span almost the whole of his career; and although they do not demonstrate any remarkable development in skill or style, they do, fairly if rather unkindly, show the artist at his best and at his worst. His quality is certainly uneven, some of the plates, especially the Longleaf Pine (pl.46) and the Christmas Rose (pl.95) being models of freshness and grace, whereas others, notably the Rose (pl.7) and more particularly the Poker-plant (pl.54) are so wooden and opaque that it is hard to believe they are by the same hand. The flattened, dive-bombing butterflies which appear in so many of his pictures are not, to my mind, an adornment; out of charity, one hopes they were forced on the artist to satisfy the catholic tastes of his naturalist patrons.

The monochromes are on the whole less satisfactory. Those which are allowed a full page are acceptable enough, though even here the "Characters of Flowers" (pl.75) with its amusing reminder of Ehret's faulty English, lacks much of the crisp quaintness of the original. The quarter- and half-page monochromes lose so much through reduction and absence of colour that one wonders if their replacement by a few additional colour plates would not have been wiser. The obscurity of one of these little illustrations (pl.16) may explain the misidentification of Thorowwax (Bupleurum rotundifolium) as Yellow-wort (Blackstonia perfoliata).

R. D. Meikle is on the staff of the Herbarium at the Royal Botanic Gardens, $K e w, U K$ 